\title{
TREATMENT OF EXPERIMENTAL UREMIA BY MEANS OF PERITONEAL IRRIGATION ${ }^{1}$
}

\author{
By ARNOLD M. SELIGMAN, HOWARD A. FRANK, AND JACOB FINE \\ (From the Surgical Research Dept., Beth Israel Hospital, and the Department of Surgery, \\ Harvard Medical School, Boston)
}

(Received for publication October 31, 1945)

The need for a temporary substitute for renal function has been emphasized recently by the report from battle fronts of a high incidence of fatal uremia in the severely wounded following kidney shutdown in the post-operative and post-transfusion period. It is probable that the acute renal damage of wounded men and in some other conditions is reversible, so that death from uremia might be prevented if retention products could be excreted through an extra-renal outlet during the healing period. Three ways of decreasing uremia by extrarenal excretion have been suggested in the past: (1) excretion through the intestinal tract, by gastro-duodenal suction and the production of diarrhea, and through the skin by the production of sweating; (2) "vivi-difusion," by which the circulating blood is submitted to dialysis outside the body and returned to the circulation (1 to 3) ; (3) peritoneal dialysis, by which fluid, introduced into the peritoneal cavity and allowed to equilibrate with the blood, is afterward removed with nitrogenous and other diffusible substances (4 to 6).

The peritoneum is an efficient dialyzing membrane ( 7$)$, but utilization of this function for the treatment of uremia $(4,6,8)$ to date has not been applied with success. ${ }^{2}$ To determine whether this method can be made practical for clinical use, studies have been made on man and animals. This report deals with the experimental data in dogs.

1 The work described in this paper was done under a contract, recommended by the Committee on Medical Research, between the Office of Scientific Research and Development and Harvard University.

2 A sucessful clinical application of the method described in this paper has been reported. Treatment of uremia after acute renal failure by peritoneal irrigation. Case report. Howard A. Frank, Arnold M. Sligman, and Jacob Fine. J. A. M. A., 1946, 130, 703.

\section{METHODS}

\section{A. Preparation of the animals}

Bilateral nephrectomy was performed with sterile precautions through posterior paravertebral incisions under ether anesthesia. One dose $(100,000$ units) of penicillin was given by vein immediately after nephrectomy and intravenous $\mathbf{5}$ per cent glucose in distilled water was given now and then thereafter, as food and fluid supplements were required. At the same time (or later under local anesthesia) two catheters were placed in the peritoneal cavity for irrigation. If the dog was to lie prone during the irrigation, they were inserted through posterior incisions, one on each side of the midline. If the dog was to lie supine during the irrigation, they were inserted through small incisions or trocar puncture wounds in each flank. To help maintain patency of the irrigating catheters in long term experiments, omentectomy was performed through the left-sided posterior incision at the time of nephrectomy.

Catheters introduced through incisions were of the large-bore mushroom-tip type, with added perforations, held just within the peritoneal cavity. Catheters introduced through trocars were of the whistle-tip (No. 14No. 20 French) type with added perforations projecting 2 to 6 inches into the peritoneal cavity. The mushroomtip catheters drained more effectively than the whistle-tip catheters. Irrigation through hollow needles or through a variety of glass irrigating bulbs designed to keep obstructing viscera or membranes from the outlet openings was unsatisfactory.

In a few experiments in which renal urea clearance was determined, urine was collected from the bladder by catheterization.

\section{B. Irrigation fluid}

Ringer's solution containing glucose, used in the early experiments, was changed later to Tyrode's solution containing the following anhydrous salts per liter: $\mathrm{NaCl} 8.0$ grams, $\mathrm{KCl} 0.2$ gram, $\mathrm{CaCl}_{2} 0.1$ gram, $\mathrm{MgCl}_{2} 0.1$ gram, $\mathrm{NaH}_{2} \mathrm{PO}, 0.05$ gram, $\mathrm{NaHCO}_{8} 1.0$ gram, and dextrose 1.5 grams. In addition, the irrigation fluid contained sodium penicillin (2500 to 5000 units per liter) and sodium sulfadiazine (6 to $12 \mathrm{mgm}$. per cent) for prophylaxis against infection, and the sodium salt of heparin ( 0.25 to $0.5 \mathrm{mgm}$. per liter) in order to minimize the intraperitoneal formation of fibrin and adhesions. Because large volumes of this solution were required (20 to 40 liters per day), it was made up in the following manner: All 
the salts (except the $\mathrm{NaHCO}_{3}$ ), together with the glucose for 18 liters of irrigating fluid, were dissolved in 2 liters of distilled water; the $\mathrm{NaHCO}_{3}$ for 18 liters of fluid was dissolved separately in 1 liter of water. ${ }^{8}$ Both solutions were sterilized by autoclaving and were added aseptically just before use to 15 liters of cooled freshly distilled water in sterile 5 gallon pyrex bottles. At the same time the sodium penicillin in powder form and sterile solutions of sodium sulfadiazine and sodium heparin were added.

\section{Method of irrigation}

Two five gallon bottles containing the irrigating solution were placed 2 to 3 feet above the level of the dog. From these the fluid flowed by syphonage through glass tubes, joined by a $\mathrm{Y}$ connecting piece to a tube constricted to control the flow rate, thence into a drip bulb to observe the flow rate, then through a glass $U$ tube immersed in water at 40 to $43^{\circ} \mathrm{C}$., and finally through pressure tubing to the inflow catheter. The outflow catheter, connected to pressure tubing filled with fluid, drained into a receiving bottle placed 0 to 3 feet below the level of the dog, so that varying degrees of suction might be produced when required, to prevent overdistention of the peritoneal cavity. The rate of flow was measured by collecting the outflow fluid into a graduated cylinder for $1 / 2$ to 1 hour.

Since it was necessary to continue peritoneal irrigation through the night in long term experiments, a means of confining the dog while keeping him prone was necessary to prevent pulling out of the catheters, or kinking of the outlet tube, which would result in fatal distention of the peritoneal cavity. More than slight motion forward or backward and turning or falling from the table were prevented by attaching a harness on the dog to the front, back and sides of a firmly anchored wooden cage placed over the table. In this way the dog was kept in a comfortable position for days and nights. The irrigating catheters were attached by glass adaptors to pressure tubing suspended from the top of the cage in such a way as to allow mobility without tugging or kinking of the tubing.

In the long term experiments water was offered freely. Protein intake was maintained, when the dog refused to eat, by forced feeding of raw eggs. Glucose, saline solution, vitamin $\mathrm{B}$ complex, vitamin $\mathrm{C}$, penicillin and sodium sulfadiazine were given intravenously daily, and whole blood transfusions whenever they were considered necessary. In the intervals between irrigation periods the dogs were removed from the table and permitted to walk. Temperature, body weight and gross and microscopic appearance of the drainage fluid were obsetved.

3 It is important not to heat the bicarbonate solution with the other salts and glucose because of precipitation of calcium and magnesium salts and the production from glucose of toxic substances (probably aldehydes) which in early experiments caused severe vomiting and occasional eosophageal ulceration, rupture and death.

\section{Determination of blood urea clearance}

In order to compare the efficiency of peritoneal irrigation with kidney function, blood urea clearance by both routes was determined from the equation (9):

$$
\text { (1) } \mathrm{C}_{\mathrm{m}}=\frac{\mathrm{UV}}{\mathrm{B}}
$$

where

$\mathrm{C}_{\mathrm{m}}$ is the maximum blood urea clearance in $\mathrm{ml}$. per minute

$\mathrm{U}=$ urea nitrogen concentration of urine or peritoneal drainage fluid in $\mathrm{mgm}$. per cent

$\mathrm{V}=$ rate of flow of urine or peritoneal fluid in $\mathrm{ml}$. per minute

$\mathrm{B}=$ urea nitrogen concentration of blood in mgm. per cent

The usual collection period for urine or peritoneal fluid was $1 / 2$ to 1 hour. Blood specimens were taken at the beginning and at the end of each collection period and an average blood concentration was calculated. The peritoneal cavity was irrigated for $1 / 2$ hour at each new rate of irrigation before determining the clearance.

\section{E. Intestinal loop and pleural irrigation}

To compare the dialyzing efficiency of the peritoneum with other membranes, a few irrigation experiments were performed in dogs with isolated loops of intestine prepared under ether or local anesthesia and studied immediately or, as in one experiment in which the remaining intestine had been anastomosed, after recovery. Irrigation was performed through catheters placed in the ends of the intestinal loop.

In a single experiment, the pleural cavity was irrigated by two catheters, one placed between two upper ribs, the other just above the diaphragm, with the dog lying supine.

\section{F. Chemical methods}

The arterial blood $\mathrm{pH}$ was measured before clotting in a syringe electrode with a Beckman potentiometer. The blood urea nitrogen was measured by the method of Karr (10) using the Klett-Summerson photoelectric colorimeter. The urea content of a protein-free filtrate of the fluid recovered from the peritoneal cavity was determined by the same method except that when cloudiness was produced by the calcium and magnesium salts, the period for color development was shortened.

\section{RESULTS}

\section{A. The effect of rate of irrigation on blood urea clearance}

Peritoneal irrigation with physiologic saline was performed at different rates of flow in two dogs nephrectomized under local anesthesia. Immediately after nephrectomy urea was injected intravenously. The flow rates ranged from 6 to 
$150 \mathrm{ml}$. per minute. The dogs lay on their backs during the experiments. The blood urea clearances so determined were plotted against the flow rate (Figure 1, curves $A$, Dogs $U_{3}$ and $U_{4}$ ). The optimum rate of flow for maximum clearance was 25 to $50 \mathrm{ml}$. per minute.

A similar study was made, using the modified Tyrode's solution in two non-nephrectomized dogs from which the omentum had been removed under ether anesthesia and which were kept prone during the experiments (Figure 1, curves B, Dogs $\mathrm{U}_{24}$ and $\left.\mathrm{U}_{25}\right)$. It will be noted that the blood urea clearances were higher in those than in the previous experiments but the optimum flow rate was about the same, 30 to $50 \mathrm{ml}$. per minute.

The higher clearances for Dogs $U_{24}$ and $U_{25}$ were due to the position of these dogs and not to the fact that they were not nephrectomized, as subsequent experimental data will show (Table I). In the prone position the abdomen tended to be more uniformly filled and the dependent viscera and mesentery probably prevented short-circuiting currents from forming between the inflow and outflow catheters.
B. Comparison of blood urea clearance by peritoneal irrigation with clearance through the kidneys

Blood urea clearances by peritoneal irrigation for dogs lying supine averaged $5 \mathrm{ml}$. per minute, while for dogs lying prone the average was 10.8 ml. per minute (Table I). Simultaneous determination of renal urea clearance was performed in Dogs $U_{2}$ and $U_{25}$. In one $\left(U_{2}\right)$, lying supine, peritoneal irrigation equalled 10 per cent of its own renal function at the time. In the other $\left(U_{25}\right)$, lying prone, peritoneal irrigation equalled 136 per cent of its own renal function at the time. Such comparisons were not extended because it seemed unlikely that valid renal clearance values were being obtained under the circumstances incident to peritoneal irrigation.

The normal blood urea clearance for dogs under carefully controlled conditions of diet, water intake and psyche has been found by several investigators (11 to 13 ) to range from 50 to $58 \mathrm{ml}$. per sq. m. of body surface per minute, when urinary flow exceeds $0.4 \mathrm{ml}$. per minute. The surface area was derived from a formula which includes

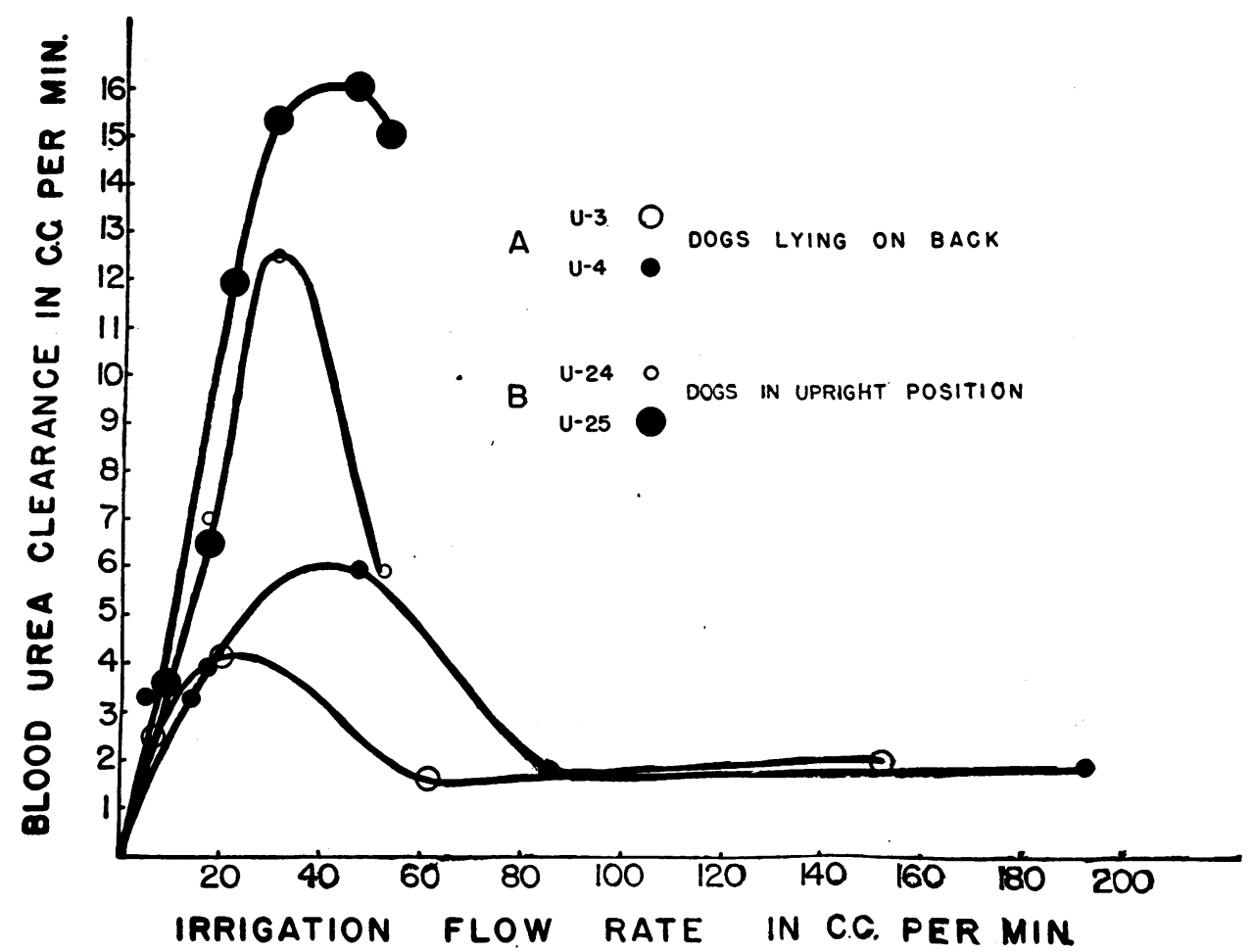

Fig. 1. Variation in Peritoneal Urea Clearance with the Rate of Irrigation 
body length as well as weight. The average surface area of our dogs irrigated in the prone position $\left(U_{8}\right.$ to $\left.U_{25}\right)$, calculated on a weight basis only from the formula (14) $\mathrm{S}$ (sq. cm.) $=11.2$ $\times \mathrm{W}$ (grams) ${ }^{2 / 8}$, equals $0.45 \mathrm{sq} . \mathrm{m}$. and the peritoneal clearances of these dogs lying prone averaged $24 \mathrm{ml}$. per sq. m. per minute. This equals
41 to 48 per cent of the average renal urea clearance value given by these investigators.

In one of this group of studies (13) an average maximum renal urea clearance of $31.4 \mathrm{ml}$. per minute was obtained in dogs varying in weight from 18 to $23 \mathrm{kgm}$. If we take this value as normal and calculate the normal renal urea clearance

TABLE I

Blood urea clearance $(\mathrm{Cm})$ by peritoneal irrigation and by kidney function

\begin{tabular}{|c|c|c|c|c|c|c|c|}
\hline \multirow{2}{*}{ Dog no. } & \multirow{2}{*}{ Dog wt. } & \multicolumn{2}{|c|}{ Peritoneal irrigation* } & \multicolumn{2}{|c|}{ Kidney function } & \multirow{2}{*}{$\begin{array}{l}\text { Nephrec- } \\
\text { tomized }\end{array}$} & \multirow{2}{*}{ Remarks } \\
\hline & & $\begin{array}{c}\text { Clearance } \\
(\mathrm{Cm})\end{array}$ & $\begin{array}{l}\text { Flow rate } \\
\text { (V) }\end{array}$ & $\mathbf{C m}$ & $\begin{array}{c}\text { Flow rate } \\
\text { min. }\end{array}$ & & \\
\hline 1 & $\begin{array}{r}\mathrm{kgm} . \\
4.5\end{array}$ & $\begin{array}{l}\text { ml. per } \\
\text { min. } \\
6.4\end{array}$ & $\begin{array}{l}\text { ml. per } \\
\text { min. } \\
24\end{array}$ & $\begin{array}{l}\text { ml. per } \\
\text { min. }\end{array}$ & $\begin{array}{l}\text { ml.per } \\
\text { min. }\end{array}$ & No & Nembutal anesthesia \\
\hline 2 & 4.6 & $\begin{array}{l}2.6 \\
4.5\end{array}$ & $\begin{array}{l}12 \\
11\end{array}$ & $22-29$ & $0.2-0.4$ & No & Morphine \\
\hline 3 & 10 & 4.1 & 20 & & & Yes & Determined immediately after nephrectomy \\
\hline 4 & 8 & 5.9 & 47 & & & Yes & Determined immediately after nephrectomy \\
\hline 5 & 6 & $\begin{array}{l}4.1 \\
5.0\end{array}$ & $\begin{array}{l}27 \\
27\end{array}$ & & & Yes & Determination on second day \\
\hline 7 & 7 & $\begin{array}{l}9.5 \\
2.7 \\
5.1\end{array}$ & $\begin{array}{l}32 \\
33 \\
33\end{array}$ & & & Yes & $\begin{array}{l}\text { Determination on second day } \\
\text { Determination on third day }\end{array}$ \\
\hline $9 \dagger$ & 11 & 19.4 & 29 & & & Yes & \\
\hline 10 & 7 & $\begin{array}{r}4.1 \\
10.0\end{array}$ & $\begin{array}{l}28 \\
29\end{array}$ & & & Yes & Determination on second day \\
\hline 11 & 5.5 & 16.0 & 32 & & & Yes & \\
\hline 13 & 5.1 & 8.8 & 19 & & & Yes & \\
\hline $16 \ddagger$ & 9.6 & $\begin{array}{l}7.4 \\
4.8\end{array}$ & $\begin{array}{l}13 \\
14\end{array}$ & & & Yes & Determination on second day \\
\hline 18 & 8.5 & 4.5 & 22 & & & Yes & Determination on second day \\
\hline 20 & 8 & 11.7 & 25 & & & Yes & Determined over $14 \mathrm{hr}$. period \\
\hline 22 & 9 & 7.7 & 36 & & • & Yes & Determination on fifth day \\
\hline 23 & 10 & 10.0 & 32 & & . & Yes & Determination on ninth day and peritonitis \\
\hline 24 & -7.8 & $\begin{array}{l}12.4 \\
14.4\end{array}$ & $\begin{array}{l}31 \\
31\end{array}$ & & & No & $\begin{array}{l}\text { Omentectomized and catheters placed } 3 \text { days } \\
\text { before experiment }\end{array}$ \\
\hline 25 & 7 & $\begin{array}{l}16.0 \\
15.3 \\
15.0\end{array}$ & $\begin{array}{l}47 \\
31 \\
53\end{array}$ & 11.2 & 1.3 & No & $\begin{array}{l}\text { Omentectomized and catheters placed } 2 \text { days } \\
\text { before experiment }\end{array}$ \\
\hline \multicolumn{2}{|c|}{ Mean Clearance } & $\begin{array}{r}5.0 \\
10.8\end{array}$ & \multicolumn{5}{|c|}{$\begin{array}{l}\text { (dogs } 1-7) \\
(\text { dogs } 9-25)\end{array}$} \\
\hline
\end{tabular}

* From equation (1) $\mathrm{Cm}=\mathrm{UV} / \mathrm{B}$, it is seen that the ratio $\mathrm{Cm} / \mathrm{V}$, which may be determined from the data given in this table, is the same as the ratio of the concentration of urea in the irrigation fluid to that in the blood at the time of the determination.

† All dogs from no. 9 on were kept in the upright position (prone).

$\ddagger$ All dogs from no. 16 on were omentectomized at the time of nephrectomy. 
for our dogs $\left(U_{9}\right.$ to $\left.U_{25}\right)$, whose weight averaged $8 \mathrm{kgm}$., as some $15 \mathrm{ml}$. per minute, then the peritoneal clearances, which averaged $10.8 \mathrm{ml}$., would be 72 per cent of the normal renal urea clearance. That the peritoneal urea clearance did not change significantly after days of irrigation may be noted from the data given in Table I.

\section{Treatment of uremia by peritoneal irrigation}

Untreated dogs usually die in uremic convulsions 72 to 120 hours after bilateral nephrectomy (15). Since some of our untreated dogs died as early as 48 to 72 hours after nephrectomy, peritoneal irrigation was started within 48 to 96 hours after bilateral nephrectomy, at a time when the blood urea nitrogen varied from 100 to $250 \mathrm{mgm}$. per cent, and when the dog was in a pre-convulsive state with vomiting, twitching, and mental stupor. Irrigation was interrupted from time to time to determine the minimal flow requirements for the prevention of uremia.

Blood urea nitrogen levels in 15 dogs dropped from 100 to $250 \mathrm{mgm}$. per cent to 20 to $50 \mathrm{mgm}$. per cent after 24 to 36 hours of nearly continuous irrigation at a flow rate of 25 to $35 \mathrm{ml}$. per minute, with accompanying prompt alleviation of the clinical manifestations of uremia. During this period the arterial blood $\mathrm{pH}$, which in several dogs had varied from 7.05 to 7.20 before irrigation, rose to 7.40 .

Once the blood urea levels had dropped to near normal, irrigation for only 8 to 10 hours out of every 24 was needed to prevent excessive accumulation of nitrogenous products and the recurrence of uremic signs. In Figures 2 to 4, which are charts of the three longest experiments, the blood urea nitrogen levels are those determined daily before the start of irrigation and represent the highest levels reached each day. The efficiency of irrigation was found not to have decreased with time. No dog died from recurrence of uremia. Dogs $U_{22}, U_{23}$, and $U_{26}$ died on the sixth, ninth, and thirteenth days respectively after nephrectomy. Most of these experiments were terminated by accidental death or by bacterial contamination of the peritoneum. A rigidly aseptic technique is virtually impossible in experiments lasting many days.

At post mortem some fibrinous adhesions were seen between loops of gut, but no effective isolation of the catheter tracts from the general peritoneal cavity was noted. There was no gross edema of the peritoneal membrane. It was for this reason that it was not considered necessary to add protein to the irrigating fluid.

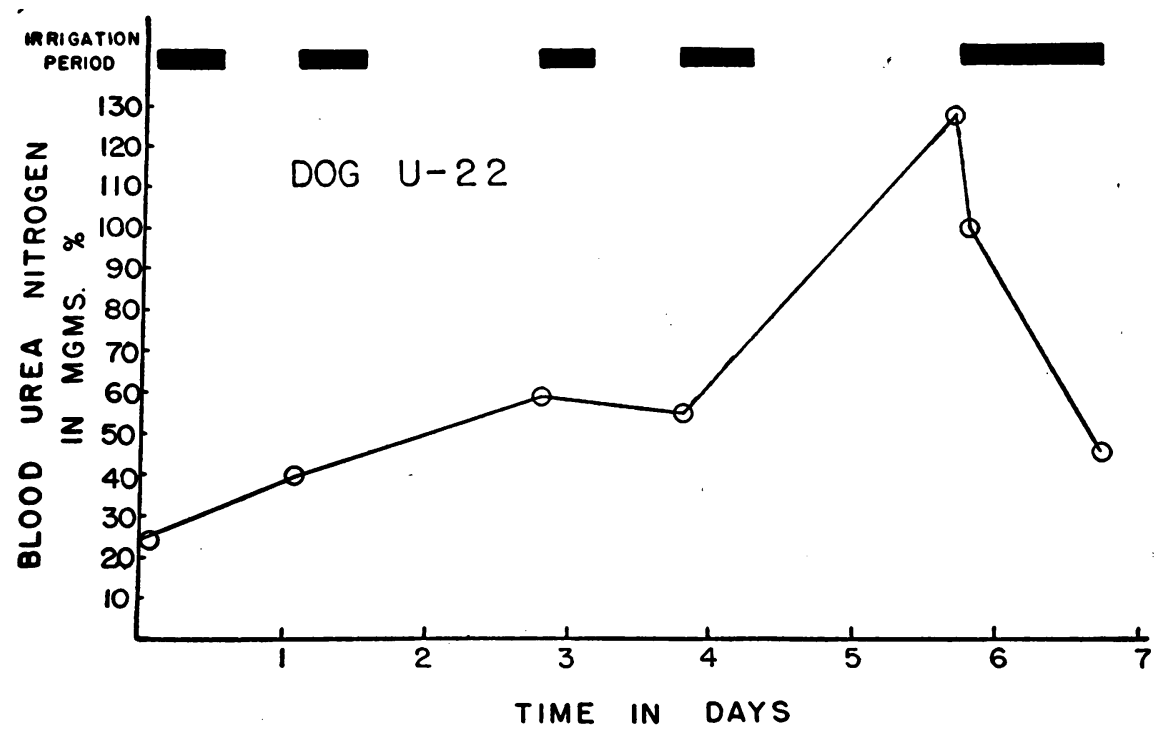

Fig. 2. Blood Urea Concentrations of Dog Following Bilateral Nephrectomy and Treated with Intermittent Peritoneal Irrigation

Specimens were taken just before irrigation was started and therefore the points represent highest levels reached between irrigation periods. 


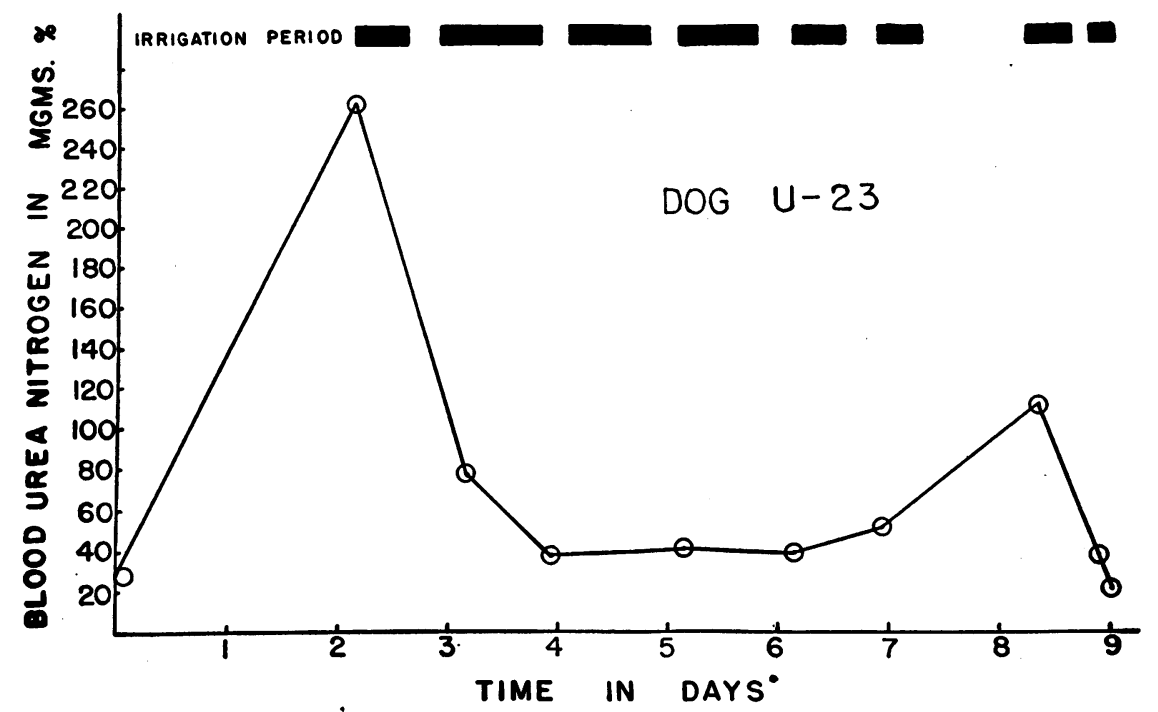

Fig. 3. Blood Urea Concentrations of Dog Following Bilateral Nephrectomy and Treated with Intermittent Peritoneal Irrigation

Specimens were taken just before irrigation was started and therefore the points represent highest levels reached between irrigation periods.

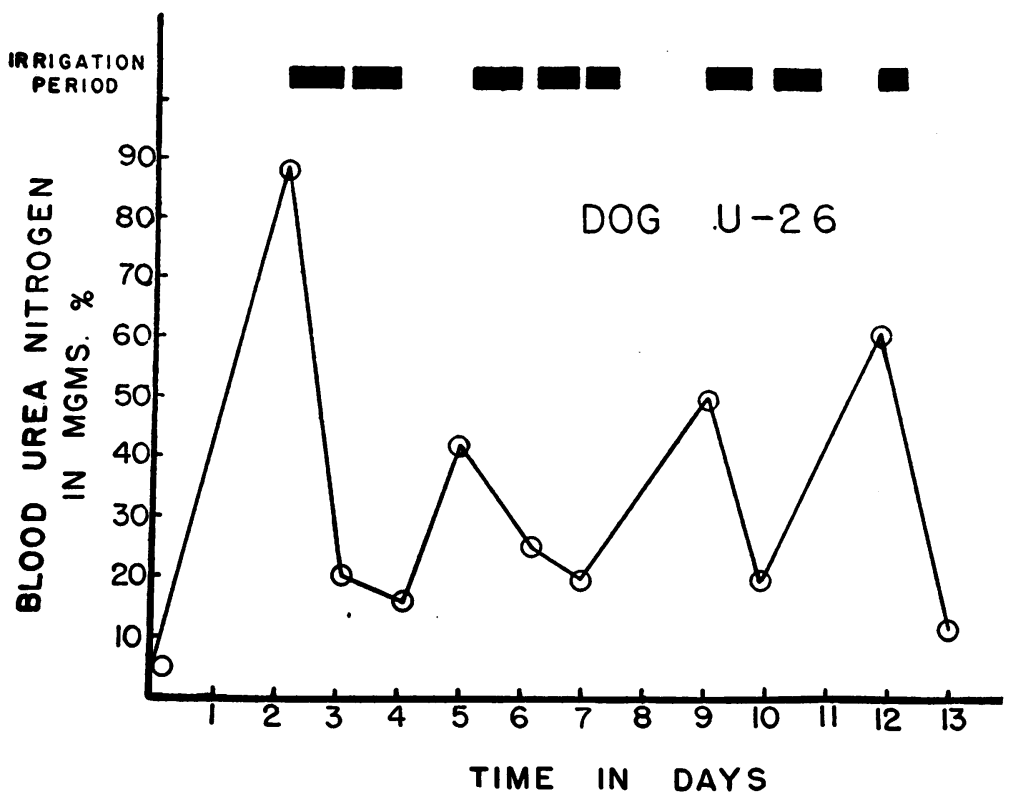

Fig. 4. Blood Urea Concentrations of Dog Following Bilateral Nephrectomy and Treated with Intermittent Peritoneal Irrigation

Specimens were taken just before irrigation was started and therefore the points represent highest levels reached between irrigation periods.

The outflow fluid contained very little protein. by leukocytes and some fibrin. Some fibrin pheIt was usually clear, with a faintly uriniferous cipitated in the receiving bottle and outlet tubing color and odor. Turbidity was caused by pre- on standing over night even in the absence of cipitation of salts or, in the presence of infection, infection. 


\section{Blood urea clearance by irrigation of isolated intestinal loops}

Irrigation of different segments of the gastrointestinal tract was performed immediately after isolation and cannulation of intestinal loops under ether anesthesia, except in experiment UG-8 (Table II) in which a recovery period of several days was allowed before irrigation was performed.

TABLE II

Blood urea clearance by means of irrigation of various parts of the gastrointestinal tract and pleural cavity

\begin{tabular}{|c|c|c|c|c|c|c|c|}
\hline \multirow{2}{*}{$\begin{array}{l}\text { Dog } \\
\text { no. }\end{array}$} & \multicolumn{5}{|c|}{$\begin{array}{l}\text { Urea clearance per } 10 \text { inches of gut } \\
\text { length in ml. per min.. }\end{array}$} & \multirow{2}{*}{$\begin{array}{c}\text { Urea } \\
\text { clear- } \\
\text { ance } \\
\text { through } \\
\text { kidneys }\end{array}$} & \multirow{2}{*}{$\begin{array}{c}\text { Urea } \\
\text { clear- } \\
\text { ance } \\
\text { through } \\
\text { pleura }\end{array}$} \\
\hline & Stomach & $\begin{array}{c}\text { Duo- } \\
\text { denum }\end{array}$ & $\begin{array}{l}\text { Je- } \\
\text { junum }\end{array}$ & Ileum & Colon & & \\
\hline UG-2 & & & $\begin{array}{l}2.4 \\
2.8 \\
2.0\end{array}$ & & & $\begin{array}{l}24 \\
24 \\
31\end{array}$ & \\
\hline UG-4 & & $\begin{array}{l}1.4 \\
2.0\end{array}$ & $\begin{array}{l}1.0 \\
1.0\end{array}$ & $\begin{array}{l}.85 \\
.80\end{array}$ & & & \\
\hline UG-5 & 0.1 & & 1.1 & & & & \\
\hline UG-7 & & & $\begin{array}{l}2.2 \\
2.3\end{array}$ & & $\begin{array}{l}0.1 \\
0.1\end{array}$ & & \\
\hline UG-8* & & & & 2.0 & & & \\
\hline Human & & & & 0.5 & & & \\
\hline PU-1 & & & & & & & 2.8 \\
\hline
\end{tabular}

* Three days postoperative.

In one experiment (UG-2) simultaneous renal urea clearance was determined. All dogs received urea $(2$ grams) intravenously. Table II shows that the clearance per 10 inches of intestine was best in jejunum, amounting to about 10 per cent of kidney function. In one human experiment with an isolated loop of terminal ileum, the clearance was too low to indicate that the intestine can be useful as a renal substitute, because over 10 feet of bowel as an isolated segment would be required to supply 10 per cent of maximum normal renal clearance ( $75 \mathrm{ml}$. per minute).

\section{E. Blood urea clearance by irrigation of the pleural cavity}

Irrigation of one pleural cavity in one dog (PU1, Table II) following intravenous injection of urea resulted in a blood urea clearance of $2.8 \mathrm{ml}$. per minute, or about $1 / 3$ of that obtained by peritoneal irrigation. The lung at post mortem was found partially collapsed.

\section{DISCUSSION}

Since crystalloids in circulating blood readily diffuse into fluid placed in the peritoneal cavity $(4,7,16$ to 20$)$ considerable amounts of nonprotein substances can be removed from the blood in uremic animals $(4,6,8)$. In one of the earliest attempts to utilize peritoneal dialysis for the treatment of clinical and experimental uremia (4), saline was introduced into the peritoneal cavity (in one case into the pleural cavity) and transient clinical improvement was observed, in that headache, vomiting, dyspnea, and depth of coma decreased for a few hours. In small uremic animals the repeated introduction into and removal of saline from the peritoneal cavity at 3 hourly intervals prolonged life for about 12 hours.

In another study (5) continuous irrigation of the peritoneal cavity of nephrectomized dogs with 5 per cent glucose solution was conducted for 5 hours per day for 2 to 3 days. The blood nonprotein nitrogen was lowered from $140 \mathrm{mgm}$. per cent to $80 \mathrm{mgm}$. per cent in many instances. But the animals did not survive longer than 3 days after therapy started. Death was said to have resulted from shock and "heart weakness," without evidence of peritonitis. It is more likely that death was due to loss of electrolytes, since electrolytes were omitted from the irrigating fluid.

Another worker (6) found that significant amounts of nitrogenous substances could be removed from the blood of nephrectomized dogs by introducing 700 to $1000 \mathrm{ml}$. of 6 per cent glucose solution into the peritoneal cavity and removing the remaining fluid (usually $500 \mathrm{ml}$.) about 5 hours later. The failure to prolong life was attributed to the severe depletion of sodium chloride which occurred concurrently.

In several clinical trials (8) of peritoneal irrigation for uremia due to mercuric chloride poisoning, using 12 to 19 liters of 2 to 5 per cent glucose solution in one half to three hours the first day, no survival beyond 24 hours was obtained even though electrolyte depletion was prevented by intravenous therapy. In our view irrigation was not carried on for a sufficient period.

The extent to which intraperitoneal infusions of glucose for the withdrawal of diffusible substances can deplete the organism of electrolytes has been shown by one investigator (21), who introduced 5 per cent glucose intraperitoneally in a 
volume about equal to 10 per cent of body weight. It was found that without a change in total body water volume, the total electrolyte concentration in body fluids was reduced ( 20 per cent of total sodium) and water was transferred from the extracellular to the intracellular compartment with resulting production of symptoms of acute dehydration.

It should be obvious that if the normal electrolyte pattern of the extracellular fluid is to be reestablished, the irrigating fluid must have a normal electrolyte pattern. There is reason to believe that in uremia "the defense of the chemical structure of extracellular fluid is of much more importance from the point of view of survival than reduction of azotemia (22)." In our experiments, an irrigation formula containing the normal electrolyte pattern of extracellular fluid was used. Irrigation lasted 20 hours daily for 2 days and 8 to 12 hours daily thereafter. The improvement in the clinical appearance of these animals following peritoneal irrigation, the drop in blood urea levels, the correction of acidosis, and the prolongation of life for from 9 to 13 days after nephrectomy, seems to us to afford good evidence that the irrigating fluid we utilize at least approximates the optimum fluid and electrolyte requirements in the circumstances.

Since the peritoneal irrigation fluid resembles a glomerular filtrate more closely than it resembles urine, it is reasonable to expect that an irrigation volume equal to or greater than that of the glomerular filtrate would be required to treat uremia. The rate of formation of glomerular filtrate in dogs, as measured by inulin or creatinine clearance, is given as $94 \mathrm{ml}$. per sq.m. per minute (23): For dogs of 0.4 to 0.45 sq.m. surface area, the glomerular filtration rate therefore is 38 to $47 \mathrm{ml}$. per minute, which closely approximates the observed optimum flow rates for peritoneal irrigation ( 30 to $50 \mathrm{ml}$. per minute). At these rates of flow, the ratio of the concentration of urea in the irrigation drainage fluid to that in blood is about $1 / 3$ to $1 / 2$ (see footnote,Table I) as compared to unity for glomerular filtrate. Therefore the efficiency of peritoneal dialysis of urea might be expected to be $1 / 3$ to $1 / 2$ that of glomerular filtration. Peritoneal irrigation may effect a higher percentage of normal renal urea excretion than these figures would indicate because glomerular excretion of urea exceeds total urinary excretion by virtue of the resorption of urea in the tubules. In uremic dogs we found that 5 to 10 gallons of irrigating solution, given over a period of 20 out of 36 hours, was necessary to restore blood levels of urea to near normal. Somewhat less fluid was necessary to maintain a normal level. The efficiency of peritoneal dialysis did not decrease with time.

Peritoneal irrigation in uremia has not yet been demonstrated to be of practical clinical value. It appears likely that at least 8 to 12 days of renal substitution therapy will be necessary before acute kidney lesions can be expected to heal sufficiently to resume function. The efficiency of peritoneal irrigation, in terms of urea clearance, suggests that our technique may prove to be the basis for an adequate clinical substitute for renal function for the period of time required to heal a reversible kidney lesion. It is likely that the healing of the acute renal lesions may be accelerated by the concurrent elimination of uremic changes in body tissues and fluids. The danger of peritoneal infection is real, but prophylactic measures in man are far more promising than in animals. The application of the method to patients is now in progress.

The use of other membranes than the peritoneum seems to hold little promise. The pleura is as vulnerable as the peritoneum to infection and not as satisfactory for urea clearance. The diffusion of nitrogenous substances into the gastrointestinal tract in uremia led one group of investigators (24) to prepare total external jejunal fistulae in nephrectomized dogs. In spite of histamine and cholagogues and saline replacement by vein, the total excretion of nitrogenous substances was not significant and survival was not prolonged. Our efforts in a similar direction in dogs and by aspiration of the intubated duodenum in one uremic patient were likewise futile. The irrigation of isolated intestinal loops avoids peritoneal contamination, but excretion of urea by this technique was inefficient.

\section{SUMMARY AND CONCLUSIONS}

1. Peritoneal irrigation was from 40 to 75 per cent as effective as normal kidney function in clearing the blood of urea. 
2. The optimum rate of flow for peritoneal irrigation in dogs was determined.

3. The irrigation fluid utilized was designed to restore and maintain the normal electrolyte composition of the plasma and the extracellular fluid, to correct acidosis, to prevent depletion of glucose and to minimize fibrin formation and the development of infection of the dialyzing membrane.

4. The life of dogs made uremic by nephrectomy was prolonged 3 to 10 days by means of peritoneal irrigation.

5. Dogs so treated did not die of uremia, but from bacterial contamination along catheter tracts.

6. Irrigation of isolated loops of intestine was much less effective than peritoneal irrigation.

Acknowledgment is due Mr. Thomas W. Barnett, Miss Gertrude Weinberger, and Mrs. R. B. Griffin for technical assistance.

\section{BIBLIOGRAPHY}

1. Abel, J. J., Rowntree, W. G., and Turner, B. B., On the removal of diffusible substances from the circulating blood of living animals by dialysis. J. Pharmacol. and Exper. Therap., 1914, 5, 275.

2. Thalhimer, W., Experimental exchange transfusions for reducing azotemia: use of artificial kidney for this purpose. Proc. Soc. Exper. Biol. and Med., 1938, 37, 641.

3. Kolff, W. J., and Berk, H. T. J., The artificial kidney : a dialyzer with a great area. Acta Med. Scandinav., 1944, 117, 121.

4. Ganter, G., Ueber die Beseitigung giftiger Stoffe aus dem Blute durch Dialyse. Muenchen med. Wchnschr., 1923, 70, 1478.

5. Rosenak, S., and Siwon, P., Experimentelle Untersuchungen ueber die peritoneale Ausscheidung harnpflichtiger Substanzen aus dem Blute. Mitt. a. d. Grenzgeb. d. Med. u. Chir., 1926, 39, 391.

6. von Jeny, A., Kann das Bauchfell bei Uramie die Rolle eines natuerlichen Dialysators uebernehmen? Ztschft. f. klin. Med., 1932, 122, 294.

7. Putnam, T. J., The living peritoneum as a dialyzing membrane. Am. J. Physiol., 1923, 63, 548.
8. Balazs, J., and Rosenak, S., Zur Behandlung der Sublimatanurie durch peritoneale Dialyse. Wien. klin. Wchnschr., 1934, 47, 851.

9. Möller, E., McIntosh, J. F., and Van Slyke, D. D., Studies of urea excretion. II. Relationship between urine volume and the rate of urea excretion by normal adults. J. Clin. Invest., 1928, 6, 427.

10. Karr, W. G., A method for the determination of blood urea nitrogen. J. Lab. and Clin. Med., 1924, 9, 329.

11. Ralli, E. P., Brown, M., and Parienti, A., The urea clearance test in normal dogs. Am. J. Physiol., 1931, 97, 432.

12. Jolliffe, N., and Smith, H. W., The excretion of urine in the dog-urea and creatinine clearances on a mixed diet. Am. J. Physiol., 1931, 98, 572.

13. Summerville, W. W., Hanzal, R. F., and Goldblatt, H., Urea clearance in normal dogs. Am. J. Physiol., 1932, 102, 1.

14. Benedict, F. G., Surface-area constant in comparative physiology. Yale J. Biol. and Med., 1932, 4, 385.

15. Harrison, T. R., and Mason, M. F., The pathogenesis of the uremic syndrome. Medicine, 1937, 16, 1.

16. Clark, A. J., Absorption from the peritoneal cavity. J. Pharmacol. and Exper. Therap., 1921, 16, 415.

17. Curtis, G. M., Die Wirkungsweise der spezifischen Diuretica nebst Beitraegen zur Lehre von der Harnabsonderung. Biochem. Ztschr., 1925, 163, 109.

18. Engel, D., and Kerekes, A., Entgiftungsstudien mittels der lebenden Peritoneums als "Dialysator." Ztschr. f. d. ges. exper. Med., 1927, 55, 574.

19. Heusser, $H$., and Werder, $H$., Untersuchungen ueber Peritonealdialyse. Beitr. z. klin. Chir., 1927, 14, 38.

20. Curtis, G. M., and Pacheco, G. A., Experimental hypochloremia. Proc. Soc. Exper. Biol. and Med., 1929, 26, 874.

21. Darrow, D. C., and Yannet, H., The changes in the distribution of body water accompanying increase and decrease in extracellular electrolyte. J. Clin. Invest., 1935, 14, 266.

22. Gamble, J. L., Personal communication.

23. Smith, H. W., The Physiology of the Kidney. Oxford University Press, New York, 1937.

24. Hessel, G., Pekelis, E., and Meltzer, H., Untersuchungen ueber die Ausscheidung harnfaehiger Stoffe in den Magendarmkanal bei nephrektomierten Hunden. I, II, III, IV and V. Ztschr. f. d. ges. exper. Med., 1933, 91, 267, 274, 307, 325, 331. 